\title{
IMMANUEL KANT OVER RAS EN TELEOLOGIE
}

\author{
Joris van Gorkom
}

"[...] deze kerel was van kop tot teen geheel zwart, een duidelijk bewijs dat wat hij zei dom was."

(Immanuel Kant, Beobachtungen über das Gefühl des Schönen und Erhabenen)

In zijn Physische Geographie stelt Kant dat na vijf opeenvolgende generaties van het kruisen met het blanke ras een kind weer blank is (PG, 313). Deze opmerkelijke berekening is ook te vinden in het werk van de natuurhistoricus Christoph Girtanner (1760-1800). Hij wil dit aantonen aan de hand van een analogie met het kruisen van planten. Het kind van een quinteroon - een 'blanke' die nog voor een zestiende deel zwart is - en een blanke zal geen enkele spoor meer vertonen van het zwarte ras. Omdat ook bij het kruisen na enige tijd de oorspronkelijke plant zonder sporen van de vermenging terugkeert, stelt hij dat de analogie tussen het kruisen van planten en dat van menselijke rassen 'volkomen' is. ${ }^{1}$

De Spaanse ontdekkingsreiziger Antonio de Ulloa (1716-1795) heeft waarschijnlijk als eerste dit fenomeen beschreven. ${ }^{2}$ De interesse in de terugkeer van de zuiverheid van het blanke ras keert vaak terug in de bestuderingen van de natuurgeschiedenis. Dat hier meer aan de hand is dan een wetenschappelijke observatie komt duidelijk naar voren in het werk van de arts William Lawrence (1783-1867). Nadat hij heeft opgemerkt dat de quinteroon zelf al geen spoor meer vertoont van het zwarte ras concludeert hij: "Bijgevolg is zelfs de wet nu bevredigd, en beschouwt ze hen voldoende wit geworden om haar volledige bescherming te genieten: zij zijn legitiem wit, en vrij." ${ }^{3}$

Onder de wilde volkeren heerst volgens Kant (1724-1804) een wilde ruwheid. ${ }^{4}$ We kunnen de 'neger' misschien wel disciplineren en cultiveren maar nooit civiliseren. Hij valt namelijk vanzelf terug in die ruwheid (KGS15/2, 887). 'Negers' zijn net kinderen. Tevens wijst Kant erop dat ze 'negers' blijven als ze zich niet met het blanke ras vermengen. Dat Kant rassenvermenging afwijst, heeft te maken met het verlies van alle kwaliteiten die het blanke ras voor heeft op andere rassen. Alleen door het vermengen van rassen kunnen er verdere mutaties plaatsvinden. Een mogelijk verlies van natuurlijke talenten moeten we zien te voorkomen. Bernasconi benadrukt terecht dat Kants "geloof dat rassenvermenging zou leiden tot de afzwakking van het blanke ras [...] meer dan speculatie [is]. Het staat centraal in zijn rassentheorie." Daarom moeten we 
tevens weten wanneer er na vermenging in het blanke ras geen 'zwarte' sporen meer te herkennen zijn.

We weten dat Kant de eenheid van de mens benadrukt. Tevens treffen we in de aantekeningen voor zijn colleges onheilspellende toekomstbeelden aan: "Alle rassen zullen uitgeroeid worden (Amerikanen en negers kunnen zichzelf niet regeren. Dienen dus slechts tot slaven), alleen niet die van de blanken. Hardnekkigheid van de indianen bij hun gebruiken is oorzaak dat ze niet in een volk met de blanken samensmelten." (KGS15/2, 878; KGS25, 840) Kant geeft niet aan hoe de niet-blanke rassen zullen uitsterven en waarom de blanken dit noodlot niet zal treffen. Het is evenwel verwonderlijk dat hij vervolgens de voortgang van de menselijke geschiedenis niet verder heeft bevraagd. ${ }^{6}$ Het geeft ons te denken over de slimme zetten van de natuur die Kant dacht te herkennen. In plaats van de andere rassen uiteindelijk nog de mogelijkheid te geven om zich te ontwikkelen, stuiten we met zijn theorie over rassen op serieuze problemen.

In de twaalf jaar tussen het verschijnen van De mundi sensibilis atque intelligibilis forma et principiis (1770) en zijn hoofdwerk Kritik der reinen Vernuft (1781) heeft Kant maar weinig gepubliceerd: een recensie over een redevoering van de Italiaanse anatoom Pietro Moscati en twee versies van een tekst over de verschillende mensenrassen. Het is dus opmerkelijk dat Kant zich voorafgaand aan de publicatie van zijn hoofdwerk vooral gericht heeft op de biologie. Op het moment dat Kant zich mengt in het debat over de menselijke diversiteit hebben de Duitse staten nog geen koloniën. De Duitse bijdrage aan de overzeese slavenhandel is gering, en relatief weinig Duitsers zijn nog op expedities gegaan. En in deze tijd (1775) schrijft Kant zijn eerste tekst over de 'verschillende mensenrassen'. We nemen deze tekst als uitgangspunt om aan te geven hoe Kant probeerde zich te positioneren in de discussie. Na Carl Linnaeus (1707-1778) en Georges Louis Leclerc de Buffon (1707-1788) komt hij met een theorie die de problemen in de classificatie van soorten moet oplossen. Eén van de sleutelbegrippen is dat van ras. $^{\text {? }}$

Hierbij gaat het vooral om de spanningen in zijn werk tussen 'hiërarchie van de rassen' en zijn kosmopolitisme. In dit artikel bespreken we de ontwikkeling en context van Kants denken over rassen. We beginnen met een kort overzicht van de voorgeschiedenis. Vervolgens staan we stil bij de manier waarop Kant hoopt zijn begrip van ras te verbinden aan het denken over een doelmatigheid in de natuur. De twee meest beroemde opponenten van zijn denken over rassen zijn Johann Gottfried von Herder en Johann Georg Adam Forster. Door hun kritiek voelt Kant zich meermalen gedwongen om zijn inzichten in nieuwe teksten uit te werken. Na lange tijd krijgt Kant dan toch de erkenning waar hij naar zocht. Hij vindt medestanders in wetenschappers als Johann Friedrich Blumenbach en Christoph Girtanner. Om mechanismen van het hedendaagse racisme te begrijpen, kunnen we er niet omheen om terug te blikken op deze geschiedenis die ons doet vragen of zoiets als kosmopolitisme 
een vanzelfsprekende en uitgemaakte zaak is. Een beroep op de menselijkheid is hierbij misschien niet voldoende om racisme tegen te gaan.

\section{Het rassenonderscheid, een slimme zet van de natuur}

Het geloof in het eerste menselijke paar uit de Bijbel wekt aanvankelijk de interesse op naar de diversiteit van mensen. In de discussies die hierop volgen zoekt Kant allereerst aansluiting bij Buffon die een monogenese verdedigt: de mens behoort tot één soort waarbij men van één eerste oorsprong van de mensheid moet uitgaan. Maar hoe kan het dat iemand met een zwarte huid niet blank wordt in koudere regionen? Hoewel er een grote bijdrage aan en interesse in de discussies over slavernij is, ontwikkelt de fascinatie voor deze vraag zich in Duitsland vooral vanuit een wetenschappelijke interesse.

Geconfronteerd met een rijke voorraad aan reisverhalen stellen velen in de $18^{\mathrm{e}}$ eeuw de vraag hoe de diversiteit aan mensen te verklaren valt. De mensheid stamt immers af van een eerste menselijke paar dat enkele duizenden jaren eerder leefde. Hoe moet men dan de diversiteit begrijpen? Ook Kant ziet zich gedwongen om deze geschiedenis te onderzoeken. In deze traditie ordent Linnaeus de levende wezens in een biologische taxonomie waarin hij tegelijk een plaats aan de mens toekent. Hierop volgt sterke kritiek. Afgezien van morele of theologische bezwaren kan Linnaeus' taxonomie de diversiteit van mensen niet verklaren. Hoewel Lord Kames (Henry Home) en Voltaire de monogenetische verklaring van de verschillen trachten te weerleggen, blijft nog onduidelijk hoe we een continuïteit binnen de diversiteit van mensen moeten begrijpen. Een blanke man die naar de warme regionen gaat wordt niet zwart. Wat ligt hier aan ten grondslag? Louter externe factoren kunnen dit in de ogen van Kant maar moeilijk verklaren, zodat een mechanische verklaring simpelweg ontoereikend is. De centrale vraag bleef onbeantwoord.

Kant wilde in deze context het begrip van ras definiëren dat tot dan toe nog onduidelijk was. Hij geeft hiermee de eerste serieuze theorie over rassen die grote invloed heeft op biologen. Zijn grote wetenschappelijke fascinatie neemt niet weg dat hij een rassenhiërarchie formuleert ${ }^{8}$ die hij in drie verschillende teksten uitwerkt. Dit wijst er alleen al op dat hij lange tijd naar erkenning voor zijn vindingen zocht. Voor hem is de huidskleur het belangrijkste criterium om het onderscheid tussen de rassen te maken, bijgevolg zoekt hij daar een verklaring voor. De wetenschappers hebben tot dan toe door een verwijzing naar het klimaat of het eten de bestendige huidskleur niet kunnen verklaren. Kant aanvaardt deze verklaring slechts ten dele. In de idee van de doelmatigheid van de natuur meent hij een ander principe te hebben gevonden.

Buffon heeft dan al aangegeven dat alle mensen tot dezelfde natuurlijke soort behoren omdat er de mogelijkheid is om vruchtbare nakomelingen voort te brengen. Volgens Kant vormen de mensen dus één en hetzelfde geslacht. De 
indeling van levende wezens volgens geslachten is gebaseerd op de verwantschap met betrekking tot de voortplanting en overerving. 'Ras' heeft vervolgens alleen betekenis als een mutatie van een vaststaande of permanente soort. En aangezien toeval en mechanische verklaringen niet toereikend zijn voor de bepaling van het rassenonderscheid moeten we volgens Kant wel uitgaan van een preformatie: de mogelijkheden zijn reeds voorgevormd in de stam. Dit betekent allereerst dat de mogelijkheden van alle rassen latent aanwezig waren bij iedere mens. Zo zal het begrip van ras datgene moeten aanduiden wat onveranderlijk is doorheen de generaties, zelfs als het klimaat verandert. Tegelijkertijd betekent dit dat de ontwikkeling van een ras onomkeerbaar is. De kleur is immers permanent. Zo kan Kant concluderen dat de mens bestemd was voor elk klimaat en elke gesteldheid van de bodem. Wat betreft de 'neger' merkt Kant op dat deze geschikt is voor zijn klimaat, zodat deze "sterk, vlezig, soepel, maar onder de rijkelijke voorziening van zijn moederland lui, wekelijk en beuzelachtig is" (VRM, 438).

Kant hoopt op de erkenning van de noodzaak van het principe van doelmatigheid in de bestudering van het levende organisme (VRM, 435). Uitgerekend het rassenonderscheid vraagt om een verklaring vanuit de doelmatigheid. Om te begrijpen dat de mens aanvankelijk bestemd is voor elk klimaat introduceert hij twee begrippen die tot dan toe nog niet in samenhang waren gedacht: kiem en natuurlijke aanleg. Kiemen liggen aan het organisme ten grondslag voor het uitwikkelen van afzonderlijke delen. Het voorbeeld dat Kant presenteert is de extra verenlaag van de vogel. Zo liggen volgens hem bij vogels van dezelfde soort kiemen ten grondslag die de ontwikkeling van een nieuwe laag veren in koudere klimaten mogelijk maken. Afhankelijk van het klimaat heeft een bepaalde kiem zich hier dus kunnen ontwikkelen. Als het de grootte of de verhouding van de delen (organen) betreft, dan spreekt Kant van een natuurlijke aanleg. De kleur van de huid is dan wel bepaald door een kiem. Maar een dikkere huid is een natuurlijke aanleg, en meermalen benadrukt Kant de dikke huid van de 'neger'.

Om het centrale punt van zijn gedachte aangaande de rassen kracht bij te zetten, bespreekt Kant een voor hem uiterst belangrijke kwestie. De nadruk die hij hierop legt was van groot belang voor zijn invloed op de biologen: de halfbloed. Hoewel rassenvermenging volgens Kant tegen de natuur ingaat (GTP, 166, 167; APH, 320), ${ }^{9}$ besteedt hij veel aandacht aan de halfbloed. Allereerst geeft de halfbloed aan dat de twee ouders tot één soort behoren. Leden van twee verschillende rassen die zich voortplanten zullen altijd kinderen krijgen waarvan de overerving van de kleur van beide ouders gelijk verdeeld is. De huidskleur geeft zich in het voortplanten dus onveranderlijk door. Daarom introduceert Kant het begrip van ras. Hiermee zet hij zich af tegen de theorie van polygenese ${ }^{10} \mathrm{De}$ huidskleur van het kind van ouders van verschillende rassen zal tussen dat van de ouders liggen. Het soortbegrip is hiermee duidelijk onderscheiden van dat van 
het ras. Hij onderscheidt het begrip van ras tevens van de variant. Het begrip van variant heeft dan bijvoorbeeld betrekking op de kleur van de ogen. Deze is in tegenstelling tot de huidskleur niet noodzakelijk overgeërfd.

In 1775 legt Kant de lezer uit dat een "neger en blanke weliswaar niet verschillende soorten van mensen (want zij behoren vermoedelijk tot een stam), maar juist twee verschillende rassen" zijn (VRM, 430). Hij omarmt Buffons soortbegrip, maar hiermee zijn nog niet 'de verschillende rassen van de mens' verklaard. Hoe de 'neger' zwart wordt blijft een probleem voor de wetenschappers van de $18^{\mathrm{e}}$ eeuw, en de vele reisverhalen, gekoppeld aan een Bijbelse traditie, maakt hen des te meer nieuwsgierig.

Laten we hierbij de enorme rijkdom aan overdrijvingen in (het gebruik van) deze reisverhalen niet onderschatten. De literatuur is voor een groot deel gekleurd door de heersende discussie over het afschaffen van slavernij. De verhalen dienen dus vaak ook om de positie van de auteur te ondersteunen. Maar waar komt de zwarte kleur vandaan? Immers, zo stelt Kant in een sectie over 'Enige merkwaardigheden van de zwarte kleur van de mens' van zijn Physische Geographie, de neger is blank bij de geboorte afgezien "van de geslachtsorganen en een ring om de navel, die zwart zijn" (PG, 312). Het zwart verspreidt zich dan vanuit deze delen over het gehele lichaam.

In 1777 is de nadruk voor Kant nog meer op de huidskleur komen te liggen, terwijl hij in 1775 bijvoorbeeld nog de gelaatstrekken erbij betrok. Wat vooral duidelijk naar voren komt, is het belang dat hij hecht aan het klimaat (PG, 285-288). Zo is de droge hitte samen met de typische regen - Kant verwijst naar Sierra Leone en enkele regionen aan de kust van Guinea - de oorzaak dat de zwarten wegrennen van zowel regen als vuur (PG, 294). Tegelijkertijd blijft deze verklaring ontoereikend voor de diversiteit van de huidskleuren van de mensen.

Kant argumenteert dat de verschillende rassen slechts te begrijpen zijn als er kiemen en natuurlijke predisposities ten grondslag liggen die zich afhankelijk van de externe omstandigheden hebben ontwikkeld. De kiemen voor de ontwikkeling van rassen zijn dus aanwezig bij elke mens, en een kiem ontvouwt zich ten behoeve van een bepaald doel. In 1777 beweert hij nog dat ijzerdeeltjes in het bloed de huidskleur kunnen bepalen - en er uiteindelijk voor zorgen dat "alle negers stinken" (VRM, 438) -, maar in 1785 wendt hij zich tot een andere theorie: phlogiston zorgt voor de zwarte huid van de 'neger'. Later hierover meer. Louter mechanische oorzaken zouden voor een ongebreidelde toename aan mogelijke variaties binnen de soort zorgen. Sommige aspecten zijn dus voorgevormd en onomkeerbaar. Het klimaat kan het kenmerkende van het ras niet ongedaan maken of veranderen. Het ras blijft. Dit is een essentieel punt voor Kant, omdat hierin het ras zich onderscheidt van andere kenmerken. Het klimaat kan een kiem activeren, maar de weg terug naar de oorspronkelijke stam is vervolgens uitgesloten (VRM, 442; BBM, 105; GTP, 166). Dit betekent tevens dat andere kiemen door externe factoren niet geactiveerd zijn. Ze zijn onderdrukt 
als één kiem zich heeft kunnen uit- of ontwikkelen. Ze zijn zeker voorgevormd in iedere mens maar niet allemaal ontwikkeld.

Een kiem en een aanleg kunnen zich door externe factoren ontwikkelen of juist terughouden. "Alleen de stamvorming kan in een ras ontaarden; deze echter, waar ze eenmaal wortel heeft geschoten en de andere kiemen heeft verstikt, weerstaat alle omvorming pas daarom omdat het karakter van het ras eenmaal in de voortplanting overwegend is geworden." (VRM, 442) In het geval van de mens is voor Kant de huidskleur cruciaal, en zo zijn er volgens hem (in 1775) vier rassen: het blanke ras, het zwarte ras, de Hindoestanen en de Kalmukken (VRM, 432). Hij presenteert op het eind van de herwerkte versie van zijn 'Von den verschiedenen Racen der Menschen' (in 1777) een ander schema. Daar presenteert hij de volgende vier rassen: "Eerste ras: hoogblond (noord. Eur.), van vochtige kou; tweede ras: koperrood (Amerik.), van droge kou; derde ras: zwart (Senegambia), van vochtige hitte; olijfgeel (Indianen), van droge hitte" (VRM, 441). Zo heeft hij dus aan het eind van de tekst de Mongolen vervangen door de Amerikaanse indianen. ${ }^{11}$

Daarnaast geeft Kant aan dat de 'blanken van donkerbruine kleur' de 'stamsoort' het dichtst naderen (VRM, 441). In zijn Physische Geographie voegt hij hieraan toe dat de "mensheid in zijn grootste volkomenheid in het ras van de blanke" is, terwijl de "gele indianen [...] al een geringer talent" hebben. "De negers zijn ruim beneden [hen], en op het laagste niveau staat een deel van de Amerikaanse volksstammen." (PG, 316; cf. GTP, 175-176) Zoals Bernasconi opmerkt is Kant niet de eerste die een dergelijke hiërarchie opstelde, maar het "was voor hem een feit dat verklaard diende te worden". ${ }^{12}$

Door de diversiteit van mensen te reduceren tot vier rassen komt Kant tegemoet aan een eis die onze kritische filosoof stelt aan het denken. De filosoof of wetenschapper moet namelijk een groot aantal soorten terugbrengen tot een beperkt aantal rassen. Zodoende kan hij zijn weg vinden doorheen de enorme diversiteit aan gegevens. Dit betekent volgens Kant ook dat de wetenschapper het levende wezen niet louter moet bestuderen in een natuurbeschrijving maar in een natuurgeschiedenis (VRM, 429, 434n). Een natuurbeschrijving richt zich op de kennis van de dingen van de natuur zoals ze nu zijn. Een voorbeeld hiervan is Linnaeus' taxonomische categorisatie van dieren en planten. Maar zo blijft de diversiteit van de menselijke rassen een probleem. De natuurgeschiedenis houdt zich bezig met wetmatigheden in plaats van arbitraire onderscheidingen. Deze wetten betreffen dat wat voorheen geweest is. Zo moet de natuurgeschiedenis analyseren welke opeenvolging van veranderingen een ras heeft moeten ondergaan om uit te komen bij de huidige plaats en omstandigheden. De natuurgeschiedenis is daarmee een ontwikkelingsgeschiedenis van het levende wezen.

Om te voorkomen dat de lezer zijn methode verwart met die van Linnaeus of Buffon verving hij de term later door 'archeologie van de natuur'. Deze 
archeologie verwijst naar "de voorstelling van de vroegere, oude toestand van de aarde, waarover men op goede gronden veronderstellingen durft te doen, ofschoon men daarbij geen zekerheid mag verwachten" (KU, §82, 428n/330n). "Hier staat het nu de archeoloog van de natuur vrij om die grote familie van schepselen (want als familie moeten we ze ons voorstellen om de genoemde continu samenhangende verwantschap grond te kunnen geven) te laten voortkomen uit de sporen van de oudste cataclysmen van de natuur, volgens ieder mechanisme dat hij kent of vermoedt." (KU, §80, 419/320) Het begrip van ras krijgt voor Kant zijn betekenis in de natuurgeschiedenis. Deze observatie van een doelmatige natuur wil verklaren hoe de menselijke soort tot dat is gekomen waar het nu toe in staat is.

Als Kant ervoor kiest om zijn eerste tekst over de rassen te laten verschijnen, wil hij vooral een nieuwe wetenschappelijke methode voorschrijven. Het voorbeeld bij uitstek om dit te verhelderen is het rassenonderscheid. In 1777 verschijnt een nieuwe versie van deze tekst in de populaire serie Der Philosoph für die Welt onder redactie van Johann Jakob Engel (1741-1802). ${ }^{13}$ Wetenschappers en recensenten tonen geen begrip voor het belang dat Kant er zelf aan hecht. ${ }^{14}$ Kants kritische hoofdwerken moeten dan nog verschijnen. Hierin positioneert hij zijn denken nog veel explicieter in het filosofische en wetenschappelijke debat van zijn tijd.

\section{Hoe de 'neger' zwart wordt}

In 1781 publiceert Kant zijn magnum opus: Kritik der reinen Vernunft. Twee jaar later verschijnt een herdruk van Der Philosoph für die Welt die voor de tweede maal zijn tekst over rassen opneemt. Weer een jaar later schrijft Johann Gottfried von Herder (1744-1803) zijn Ideen zur Philosophie der Geschichte der Menschheit waarin hij er niet omheen kan kritiek te uiten op de theorie over rassen. Nota bene een voormalige leerling van Kant bekritiseert zijn vernieuwende inzichten. Daarbij komt nog dat uitgerekend Herder de waardering van de wetenschappers krijgt waar Kant met zijn kritische werk zo naar verlangt.

Wat is precies met ras bedoeld als men dit begrip wil gebruiken voor de onderverdeling binnen de soort? Kant geeft een aanwijzing in zijn Kritik der reinen Vernunft:

Als ik verstandige lieden zie redetwisten over de kenmerken van mensen, dieren of planten, of zelfs van de lichamen in het rijk der mineralen - waarbij sommigen dan bijvoorbeeld specifieke, uit de afstamming voortkomende kenmerken der volkeren, of duidelijke erfelijke verschillen van families, rassen enz. aannemen, terwijl anderen volhouden dat de natuur op dit punt volstrekt dezelfde voorzieningen heeft getroffen, en dat alle verschillen louter op uiterlijke toevalligheden berusten - dan hoef ik alleen de aard van het object maar in beschouwing te nemen om te begrijpen dat geen van beide groepen ooit met 
inzicht in de aard van dat object kan spreken, omdat het daarvoor veel te diep verborgen ligt. (KRV, A667/B695)

Herder tracht op basis van de wetenschappelijke theorieën tot een begrip van de menselijke geschiedenis te komen. Hij benadrukt dat de mens 'ein Mittelgeschöpf' is onder de dieren op aarde, en er is slechts sprake van één en dezelfde mensensoort. Dit neemt niet weg dat er volgens hem een continuïteit is tussen het organische en het anorganische. Het kenmerkende van de mens is volgens hem het feit dat deze rechtop staat. Herders beschrijving bevalt Kant echter niet, al was het maar omdat hierin de plaats van de mens vooral vanuit het geofysische tot stand komt. De menselijke rede is slechts een afgeleide van zijn houding. Kant vertolkt een andere visie dan Herder, en het verschil komt goed naar voren in hun duidingen van het feit dat de mens op twee benen staat.

In zijn 'Mutmasslicher Anfang der Menschengeschichte' stelt Kant dat hij de menselijke geschiedenis wil laten beginnen met de 'eerste mens' die kon 'staan en gaan', 'spreken', 'betogen, dat wil zeggen volgens samenhangende begrippen spreken, denken derhalve". Hij onderstreept dat dit verworven vaardigheden zijn. Deze vaardigheden zijn niet 'ingeschapen', want "dan zouden ze erfelijk zijn, wat in strijd is met de ervaring". Kant heeft het thema van de erfelijkheid reeds meermalen behandeld in eerdere teksten. Nu wijst Kant erop dat de houding van de mens een verworven eigenschap is. Dat de mens rechtop staat is niet natuurlijk.

Kant is tot deze conclusie gekomen op basis van het werk van de Italiaanse anatoom Pietro Moscati (1739-1824). In 1771 schrijft hij een recensie over de redevoering van Moscati waarvan net een Duitse vertaling verschenen is. ${ }^{15}$ Moscati argumenteert daarin dat de opstaande houding van de mens niet begrepen kan worden vanuit een biologische aanpassing. De houding zorgt juist voor problemen en is biologisch gezien niet voordelig voor de soort. Als Moscati vervolgens opmerkt dat de houding hiermee 'gedwongen en onnatuurlijk' is, wekt hij Kants interesse.

Kant ziet hierin het bewijs dat de mens rechtop is gaan lopen nadat de rede hem gedwongen heeft om een andere houding aan te nemen dan de oorspronkelijke, dierlijke houding. Hij concludeert dan dat in de mens

ook een kiem van rede is gelegen, waardoor hij, wanneer zoiets zich ontwikkelt, voor de gemeenschap bestemd is, en door middel waarvan hij bestendig de hiervoor geschikte houding, namelijk de tweevoetige, aanneemt, waardoor hij aan de ene zijde oneindig veel op de dieren wint, maar ook hiermee de ongemakkelijkheden voor lief moet nemen die eruit voortkomen dat hij zijn hoofd zo trots boven de oude kameraden heeft verheven (RMS, 425).

De poging om de ontwikkeling van de menselijke soort te begrijpen in continuilteit met het dier zou de waardigheid van de mens ontnemen. De 
menselijke rede zorgt juist voor een radicale breuk met het natuurlijke. De houding van de mens getuigt hiervan. Herder beschrijft echter niets anders dan een continuïteit.

Afgezien van de filosofische verschilpunten stoort Kant zich nog meer aan de invloed die Herders werk heeft op wetenschappers. Enkele jaren eerder publiceert hij zijn Kritik der reinen Vernunft. Dat Herders werk positief wordt ontvangen, kan Kant maar moeilijk verkroppen. ${ }^{16}$ Daarvoor vindt hij Herders boek te lichtzinnig en poëtisch: te veel verbeeldingskracht en te weinig rede. Op verzoek van de redacteur van Allgemeine Literatur-Zeitung, Christian Gottfried Schütz (1747-1832) (KGS10, 394) schrijft hij een recensie over Herders boek. Het is dus niet verwonderlijk dat het thema van de houding van de mens en de rede terugkeert in Kants discussie met Herder. Zo schrijft hij over Herders mens: "er bekam Vernunft, durch die aufrechte Stellung" (REC, 48).

Kant recenseert het eerste en het tweede deel van Herders boek. Hoewel ze anoniem verschijnen herkent Herder al bij de eerste recensie de auteur. Op het moment van de publicatie van die eerste recensie, werkt Herder aan zijn tweede deel. Hierin betwijfelt hij het bestaan van de rassen: "Zo hebben enkelen gewaagd bijvoorbeeld vier of vijf afdelingen [...], die oorspronkelijk volgens streken of geheel volgens kleuren gemaakt waren, rassen te noemen; ik zie geen oorzaak voor deze benoeming." De impliciete verwijzing naar Kant is duidelijk. ${ }^{17}$ Tevens benadrukt Herder een menselijke broederschap. De mens en de aap behoren dan volgens hem tot andere soorten, maar zowel de Amerikaanse indianen als de negers zijn 'je broeder': "Hen zul je dus niet onderdrukken, niet vermoorden: want hij is een mens zoals jij dit bent; met de apen mag je geen broederschap aangaan." Het punt van Herder is kort en bondig: er zijn geen rassen, "noch vier, noch vijf rassen", en ook geen "uitsluitende variëteiten [...] op aarde. De kleuren gaan in elkaar over [...]" ${ }^{18}$ Herder gaat dus uit van een gradueel verschil in plaats van de classificaties van rassen die Kant geeft. De huidskleur kan volgens hem geen bepalende factor zijn.

Kant stelt dat juist de kleur een permanentie heeft die erop duidt dat er kiemen zijn. In de ogen van Herder verklaart een theorie over kiemen "eigenlijk niets: want de kiem is al een product en waar deze is, moet een organische kracht zijn die deze vormt". ${ }^{19}$ Herder betwijfelt de meest fundamentele begrippen van Kants ideeën over de diversiteit van mensen. Hij benadrukt dus dat het niet zinvol is om te spreken over rassen en kiemen. Er zijn slechts organische krachten in het levende wezen. Met zijn begrip van organische krachten hoopt Herder af te komen van zware metafysische claims. Hij wil zich juist baseren op de ervaring. Zo hoopt hij de diversiteit van mensen te verklaren door te wijzen op het klimaat. Deze klimatologische factor noemt Herder de 'genetische Kraft'. Zo komt de menselijke ziel geleidelijk tot stand door een kracht in de natuur. Deze kracht huist namelijk in de materie. Het organische en het anorganische vloeien langzaam in elkaar over. Later herhaalt Herder zijn punt tegen Kant: 
"Voorgevormde kiemen die sinds de schepping klaar liggen, heeft geen oog gezien; wat wij vanaf het eerste moment van het worden van schepping bemerken zijn werkende organische krachten." (Cf. REC, 50) ${ }^{20}$

Het centrale punt voor Kant om zich tegen Herder te keren heeft te maken met de poging van Herder om een vertoog over kiemen te vervangen door dat over een organische kracht. Kant benadrukt de doelmatigheid die hij koppelt aan de begrippen van kiem en aanleg. Zo vindt hij het vooral een slimme zet van de natuur om "haar schepsel door verborgen innerlijke voorzorgen op allerlei toekomstige omstandigheden uit te rusten, opdat ze zich in stand houdt". Het is dus volgens hem allereerst "bewonderswaardig" dat de mens zo 'geschapen' is dat deze aanvankelijk bestemd is voor elk klimaat (VRM, 434; KU, §68, $383 / 283$ ). Herder herkent niet de toegevoegde waarde van een vertoog over rassen voor de duiding van de diversiteit binnen de menselijke soort. Hij zet zijn punt kracht bij door erop te wijzen dat niemand in staat is geweest om een kiem te observeren. Geen oog heeft ze gezien.

Echter Herder heeft een ander begrip van kiem in gedachte dan dit door Kant is voorgesteld. Het is dus niet verwonderlijk dat Kant vervolgens probeert om Herder op het belang van kiemen te wijzen en een preformatie te verdedigen. ${ }^{21}$ Zo schrijft hij later in zijn Kritik der Urteilskraft dat hij een "systeem van de generieke preformatie" prefereert. Deze stelt dat "het productieve vermogen van de voortbrengers [...] overeenkomstig de innerlijke doelmatige aanleg van hun soort, en dus hun specifieke vorm, in aanleg (virtualiter) gepreformeerd is" (KU, §81, 423/324). Niet veel later voegt hij hieraan toe dat hij deze positie verkiest omdat hierin "met de kleinst mogelijke inzet van het bovennatuurlijke alles wat na het eerste begin volgt aan de natuur over[gelaten wordt] (zonder evenwel iets over dat eerste begin, waarop de natuurwetenschap überhaupt strandt, te bepalen, met welke keten van oorzaken ze dat ook zou willen proberen)" (KU, §81, 424/326). Kant stelt dus strikte grenzen aan dit systeem, hoewel dit impliceert dat er een bijzondere oorzaak aan het eerste begin ten grondslag ligt. Alleen over deze oorzaak kan de wetenschap niet oordelen. Deze is niet te begrijpen vanuit een mechanische verklaring.

Wat voor Kant op het spel staat is de wetenschappelijke status van het begrip van ras. Hierin probeert hij het natuurlijke mechanisme te verbinden aan een andere vorm van causaliteit: doelmatigheid. In zijn recensie brengt Kant in dat de organische kracht uiteindelijk niet veel verduidelijkt. Herder probeert volgens Kant om dat "wat men niet begrijpt uit datgene te [...] verklaren wat men nog minder begrijpt" (REC, 54). Hiermee laat hij het raadsel van de kiemen verder onbesproken. Met zijn eigen kritische werk in het achterhoofd onderstreept Kant dat een begrip als organische kracht niet door de ervaring gekend kan worden. Hij wil het gebruik van wetenschappelijke begrippen zo veel mogelijk beperken tot de ervaring. Desondanks zal er een beroep gedaan 
moeten worden op iets dat niet te verklaren is door middel van mechanische wetten.

Gezien de vele afwijzende reacties is het niet verwonderlijk dat Kant al snel probeert om zijn ideeën nogmaals uiteen te zetten. Kant kan nu slechts concluderen dat de "indeling van de mensensoort in rassen" Herder niet bevalt, "vermoedelijk omdat het begrip van een ras voor hem niet duidelijk bepaald is". Vervolgens keert hij Herders gedachte over de kiemen en de organische kracht om. Zo stelt hij dat men de "natuurbepaling van de vormende natuur ook wel kiemen of oorspronkelijke predisposities kan noemen" (REC, 62).

Niet alleen Herder heeft Kants recensie opgemerkt. De filosoof Karl Leonhard Reinhold (1757-1823) schrijft een anonieme reactie op Kant. ${ }^{22}$ De naam van Reinhold keert nog enkele keren terug in deze discussie. Herder blijft tot dan toe tijdgenoten als Reinhold inspireren die in zijn tijdschrift Der Teutsche Merkur ruimte biedt aan kritiek op Kant. Omdat Reinhold reageert op Kants eerste recensie kan deze in de bespreking van het tweede deel nog wel ingaan op Reinholds kritiek (GTP, 56-58).

Als Kants tweede recensie van Herders Ideen op 15 november 1785 verschijnt werkt hij tevens aan zijn tweede tekst over de rassen, publiceert getiteld 'Bestimmung des Begriffs einer Menschenrace' (1785). Weer een paar maanden later schrijft Kant zijn 'Mutmasslicher Anfang der Menschengeschichte' (1786). Hij voelt zich gedwongen zijn ideeën over erfelijkheid uit eerder werk opnieuw uit te leggen. Zijn denken stuit nog steeds op weerstand. De twee teksten beschouwt men daarom vaak terecht als een weerwoord op Herders boek.

Kant benadrukt in 1785 dat het soortbegrip er allereerst op duidt dat een soort onveranderlijk is. Deze constatering is niet zonder belang. Zeker als we beseffen dat hij zijn theorie over rassen nogmaals uiteen wil zetten in reactie op Herder. Om de doelmatigheid van het rassenonderscheid te benadrukken, richt Kant zich op de 'neger'. Deze doelmatigheid is immers bij "geen ras zo duidelijk te bewijzen" als bij het "negerras". Kant beperkt zich daarom tot de huidskleur van de 'neger'. Hoewel hij zich eerder nog beriep op ijzerdeeltjes in het bloed wijst hij in 1785 op de aanwezigheid van phlogiston in de lucht. De chemicus Georg Ernst Stahl (1659-1734) kwam tot zijn theorie over phlogiston toen hij wilde verklaren waarom materialen brandbaar zijn. Bij verbranding komt dit element volgens hem vrij. Kant heeft in 1785 colleges gegeven over de scheikunde waarbij hij stilstaat bij phlogiston. Echter, Antoine Lavoisier (17431794) weerlegde twee jaar eerder Stahls theorie van phlogiston aan de Académie des sciences. Hij bewees de invloed van zuurstof op het proces van verbranding en toonde aan dat phlogiston niet bestaat. Het is echter niet waarschijnlijk dat Kant in 1785 van deze nieuwste ontdekking op de hoogte is.

Hij stelt allereerst dat het bloed zwart kleurt als er te veel phlogiston in zit. 
$\mathrm{Nu}$ geeft de sterke en door geen enkele netheid te vermijden geur van de neger anleiding te vermoeden dat zijn huid zeer veel phlogiston uit het bloed wegwerkt, en dat de natuur deze huid zo georganiseerd moet hebben, dat het bloed zich bij hem in veel grotere mate hierdoor dephlogistiseren kan dan bij ons gebeurt; waar het laatste meestal een bezigheid van de longen is (BBM,103).

De 'echte neger' woont in gebieden waar de lucht "zo gephlogistiseerd" is dat "Engelse matrozen" zich met gevaar voor eigen leven in deze gebieden begeven. Hun longen kunnen de phlogiston niet genoeg wegwerken, zodat het voor Kant "van de natuur zeer wijselijk" is om de huid van de 'neger' "zo te organiseren dat het bloed" kan dephlogistiseren. Het bloed moet dus de phlogiston verwerken en deze schijnt aan de uiteinden - "onder de huid zelf" - zwart door (BBM, 103).

Met het soortbegrip benadrukt Kant de uiterste grenzen. Als Herder uitgaat van een continuïteit tussen soorten, tussen het organische en anorganische, etcetera, dan neemt hij Kants kritische onderzoek niet serieus genoeg. Het onderscheid tussen de mens en andere organismen vervaagt als we niet vasthouden aan bepaalde principes. Voor Kant kan men met het principe van doelmatigheid een verklaring geven over de slimme zetten van de natuur. Zoals Schütze Kant vertelt, is Herder nogal aangedaan door de 'anonieme' recensent. Gezien de wijdverbreide interesse in het werk van Herder kan Kant rekenen op kritiek (KGS10, 398). In Reinholds Der Teutsche Merkur publiceert Johann Georg Adam Forster (1754-1794) zijn 'Noch etwas über die Menschenracen. An Herrn Dr. Biester' (1786). Hierin reageert hij op Kants werk.

Forster was vooral bekend voor zijn wetenschappelijke reisverhalen, en uitgerekend hij beklemtoont Kants onjuiste wetenschappelijke instelling. Hij heeft al vroeg de reputatie van een gerenommeerd wetenschapper verkregen. Hij reisde namelijk tussen 1772 en 1775 met zijn vader Johann Reinhold Forster mee op een expeditie van James Cook over het zuidelijk halfrond en hij schreef lange verhandelingen over wat hij zag en verzameld had. Forster is dus geen onbekende in deze discussie, zodat Kant zich gedwongen voelt om nog explicieter de methodologie van zijn rassentheorie uit te leggen. Meer dan Herder vestigt Forster de aandacht op Kants begrip van ras.

Forster kiest voor een polygenese. Als Kant in zijn 'Mutmasslicher Anfang der Menschengeschichte' begint met het eerste oorspronkelijke paar in het paradijs denkt Forster dat Kant uitgaat van een zinvolle inbreng vanuit de Bijbel. Forster leidt uit Kants werk af dat "een kind van een [...] paar in Europa verwekt moet worden om hun van nature eigen huidskleur zonder tweeduidigheid te ontdekken". ${ }^{23}$ Een positie die polygenese denkt te weerleggen, is voor Forster echter onmiddellijk verdacht: deze beroept zich op een autoriteit die buiten de ervaring of de wetenschap geplaatst is. Wat Forster over het hoofd ziet, is dat Kant in zijn teksten over rassen spreekt over een menselijke stam in plaats van 
een eerste menselijke paar. Hij ziet in zijn reactie de polemische toon van Kants tekst over de menselijke geschiedenis over het hoofd.

Kant begint zijn tocht met datgene wat de rede niet kan afleiden uit natuurlijke oorzaken, namelijk "het bestaan van de mens". Dit is dus gegeven, maar geen natuurlijke oorzaak is toereikend genoeg om dit te verklaren. Hier moet de natuurhistoricus beginnen. Of nog preciezer: hij moet beginnen met volwassenheid, "daar hij [de mens] de moederlijke hulp moet ontberen". Kant laat de geschiedenis aanvangen met een menselijk paar "zodat hij zijn soort voort kan planten". En er is (vermoedelijk) slechts één paar, want "wanneer de mensen in elkaars omgeving en toch vreemd voor elkaar zouden zijn" dan zou er "terstond twist ontstaan". Zonder dit vermoedelijke begin kunnen we de natuur ervan beschuldigen dat ze het bij voorbaat onmogelijk heeft gemaakt om nog tot een samenleving te komen. De rede kan hier dus een 'leidraad' bevestigen aan de ervaring.

Deze eerste mens beschikt op dat moment reeds over de nodige vaardigheden: hij kan lopen, staan, gaan, spreken, betogen en denken. Kant neemt aan dat de eerste mens "over deze vaardigheden beschikte, om alleen de ontwikkeling in overweging te nemen van het zedelijke in zijn doen en laten, dat die vaardigheden noodzakelijk vooronderstelt" (MAM, 111/137). Forster herkent de samenhang tussen Kants 'Bestimmung des Begriffs einer Menschenrace' en zijn 'Mutmasslicher Anfang der Menschengeschichte'. Hij slaat echter geen acht op Kants kritische werk. In plaats van te wijzen op Kants fascinatie voor de wetenschap verwijt hij hem bezig te zijn met filosofisch of theologisch geneuzel. Kant heeft volgens hem geen aandacht voor empirisch onderzoek. Maar Kant wil zich in zijn uiteenzetting over de menselijke geschiedenis niet beroepen op een theologische grondslag. Van belang is de menselijke rede.

Kant maakt in de ogen van Forster gebruik van een filosofisch principe dat niet gebaseerd is op empirisch onderzoek. De ervaring moet in de discussie centraal staan. Een essentieel punt in het commentaar is de nadruk op een theologische inspiratie in Kants teksten over de rassen. Dit is slechts "een wetenschap van goden en niet van mensen" ${ }^{24}$ Later schrijft Forster in een brief aan Heyne dat hij allereerst een "ander gezichtspunt [wil] aanbieden" zonder dat men daar "met apodictische zekerheid [...] over kan spreken". ${ }^{25}$ Een filosofische of theologische inbreng in de discussie over de menselijke soort is schadelijk. Kant heeft hem "in een cirkel rondgeleid" en een begrip laten vinden "dat hij reeds in de vooronderstelling gegeven had". Hij houdt zich slechts bezig met conceptuele analyses in plaats van empirische observaties. Hierdoor hoopt Forster dat hij hem kan dwingen om de "zaak van een andere kant" te bekijken. ${ }^{26}$

Niet lang na de publicatie van Forsters tekst richt Reinhold zich op het werk van Kant. Deze verschuiving is niet onbelangrijk. Niet alleen maakte Reinholds Briefe über die Kantische Philosophie (1786-1787) het kritische werk toegankelijk; tevens geeft hij Kant in 1788 ruimte om in Der Teutsche Merkur in 
te gaan op zijn rassentheorie. In 1787 vraagt hij Kant om een officiële reactie op zijn Briefe (KGS10, 497-500). Kant antwoordt (KGS10, 513-516), en hij laat in 1788 een artikel verschijnen. Hierin geeft Kant de gewenste erkenning (GTP, 183-184). Belangrijker nog is dat Kant zich in die tekst hoofdzakelijk richt op Forster. Forster tast volgens hem in het duister als het gaat om het begrip van ras. Hij hoopt aan te tonen dat de weerstand tegen zijn natuurgeschiedenis berust op een misvatting. Forster werkt namelijk net als hijzelf aan een natuurgeschiedenis.

\section{Het teleologische principe}

Kant heeft inmiddels een tijdschrift aan zijn zijde gevonden en laat in 1788 zijn laatste artikel over de menselijke rassen verschijnen: 'Über den Gebrauch teleologischer Principien in der Philosophie'. Terecht wijst men op het belang van deze tekst voor zijn besluit om een kritiek van het teleologische oordeelsvermogen toe te voegen aan zijn reeds geplande Kritik des Geschmacks.

Aangezien Forster zijn commentaar hoofdzakelijk richt op het begrip van ras besteedt Kant vooral aandacht aan één vraag: 'Wat is een ras?' Kant beklemtoont hiermee wederom dat deze vraag noodzakelijk is vanuit het gezichtpunt van de natuurgeschiedenis.

Het woord staat in het geheel niet in een systeem van natuurbeschrijving, vermoedelijk is het ding zelf dus ook bovenal niet in de natuur. Alleen het begrip, zoals deze uitdrukking betekent, is desalniettemin gegrond in de rede van iedere waarnemer van de natuur die een gemeenschap van oorzaken toebedenkt van een verervende kenmerkende eigenschap van verschillende gebastaarde dieren die in het geheel niet in het begrip van hun soort ligt, weliswaar een oorzaak die oorspronkelijk in de stam van de soort zelf ligt. (GTP, 163)

Forster verkiest een polygenese. Hiermee begeeft hij zich toch op gevaarlijk terrein. Hij spreekt over het begin van de menselijke diversiteit en dit behoort volgens Kant tot de natuurgeschiedenis. Dit kan de wetenschapper niet door middel van de ervaring bevestigen. Een beroep op het begrip van ras moet volgens Kant de diverse ontwikkelingen van de mensheid verklaren. Dit is wat de rede ook eist: het reduceren van deze diversiteit tot een minimum aantal verschijningsvormen op basis van een wet.

Zo heeft Kants denken het voordeel dat hierin de minste aanspraak is gemaakt op iets bovennatuurlijks. Zijn teksten hebben dus niet die theologische inspiratie die Forster meent te herkennen. Het gaat hem om een wetenschappelijk begrip waarin zo min mogelijk gebruik wordt gemaakt van een begrip van het bovennatuurlijke of onverklaarbare. Hierin vindt Kant ook de grond om te spreken van een teleologisch principe. Dit principe legt een doelmatigheid in de natuur bloot waarmee een andere wetmatigheid is gedacht dan louter mechanische. Beide wetmatigheden komen samen in het begrip van ras. Ras 
veronderstelt niet verschillende menselijke stammen. Er is slechts één stam, maar er zijn voorgevormde kiemen aanwezig in de stam.

Een teleologische principe (de doelmatigheid) helpt de wetenschapper bij het onderzoek. Het opdelen van de menselijke soort in verschillende rassen moeten we allereerst beschouwen als een slimme zet van de natuur. Hierdoor is de mens in staat om in elk klimaat te leven. De mens is hiervoor voorbestemd. Het lukt Kant echter niet om Forster te overtuigen van een redelijk gebruik meer kantiaans geformuleerd: regulatief gebruik - van het begrip van ras. Als Forster niet veel later terugblikt op zijn discussie met Kant stelt hij dat hij uit "gebrek aan filosofische voorkennis en vast nog meer feitelijk, aangezien ik het filosofische jargon niet begrijp [...] met Kant in een strijd [geraakte]". Hij benadrukt het gevaar dat hij loopt om publiekelijk af te gaan. Kant heeft zichzelf namelijk "met zijn kunsttaal in de meest onoverkomelijke, meest stekelige vorm van de gejaagde egel samengerold, zodat men geloven kan dat hem niets gebeuren zal". ${ }^{27}$

Forster blijft op zijn zachtst gezegd kritisch. Zo schrijft hij in verschillende brieven: "[Kant] kan me door alle listen niet bepraten dat hij in de zaak van de mensenrassen gelijk heeft. Wanneer ik de tijd heb wil ik me nog eenmaal aan dit thema wijden, echter niet op polemische wijze. Mijn volgende studie, wanneer ik vrije tijd heb, zal de kantiaanse filosofie zijn waarmee ik zelfs graag in het reine ben." Kant heeft immers nog geen "opponent" gevonden "die tegen hem is opgewassen". Forsters beeld van Kant is in de tussentijd niet veranderd. Hij blijft in zijn ogen een "archisofist en archischolastiker" ${ }^{28} \mathrm{Hij}$ is een "Metafysicus" die ons "de regels [heeft] willen voorschrijven voor het bepalen van de variëteiten binnen de menselijke soort, regels die de natuur niet erkent". ${ }^{29}$ In zoverre heeft hij Forster in ieder geval niet kunnen overtuigen als hij zijn cirkelredeneringen tentoonspreidt. In plaats daarvan gaat Forsters filosofische voorkeur nog steeds uit naar Herder.

Aanvankelijk wil Kant slechts een Kritik des Geschmacks schrijven. Naar aanleiding van de voorgaande discussies beseft Kant dat hij zijn laatste boek moet voorzien van een kritiek van het teleologische oordeelsvermogen. In plaats van de tijd te verspillen aan het schrijven van een derde recensie op Herders boek besluit Kant zich te concentreren op de derde kritiek. Met dit deel hoopt hij opnieuw erkenning te krijgen vanuit wetenschappelijke kring. Het is echter opmerkelijk dat een verhandeling over de rassen en kiemen ontbreekt in de Kritik der Urteilskraft. Afgezien hiervan herkennen we andere begrippen: aanleg, stam, het levende wezen. Kant heeft ook de rol van de kiemen en rassen ogenschijnlijk ingeperkt.

Om dit te begrijpen biedt Kants 'Über den Gebrauch teleologischer Principien in der Philosophie' een eerste aanwijzing. Hoewel hij vooral ingaat op Forster verwijst hij ook naar Johann Friedrich Blumenbach. Kant wil hem attenderen op zijn leer over rassen. Blumenbach is op dat moment een 
vooraanstaand antropoloog en anatoom. Als hij toenadering zoekt tot de wetenschap schrijft Kant dat hij "een [...] bevoegdheid, ja behoefte om van een teleologisch principe uit te gaan waar ons de theorie ontgaat [...] [heeft] proberen te bewijzen in een kleine proefneming over de mensenrassen" (GTP, 159).

Kant beseft terdege dat hij eerder heeft aangetoond dat er een behoefte aan een teleologisch principe aanwezig was. Blumenbach kan dit niet ontgaan zijn. Kants teksten moeten duidelijk maken dat dit principe vooral zin heeft voor de bestudering van de rassen. Hij wil Blumenbach herinneren aan zijn eigen "kleine proefneming over de mensenrassen". Het begrip van ras heeft nog geen wetenschappelijke erkenning gevonden. De toenadering tot Blumenbach heeft ook consequenties voor Kants begrip van kiem. Deze geschiedenis speelt op de achtergrond als Kant in 1789 besluit om aan zijn Kritik des Geschmacks een kritiek van het teleologische oordeelsvermogen toe te voegen. Het resultaat, de Kritik der Urteilskraft, voltooit hij in 1790.

\section{De erkenning door Johann Friedrich Blumenbach (1752-1840)}

Met het begrip van ras heeft Kant willen laten zien hoe een doelmatigheid verankerd is in de natuur van het levende wezen. En hij houdt tot en met 1788 vol dat kiemen het fenomeen van het rassenonderscheid kunnen verklaren. Hoewel Blumenbach niet de begrippen van ras en kiem hanteert, komen hun bevindingen in vele opzichten overeen. Dit wil Kant laten zien, en hij stuurt een exemplaar van zijn Kritik der Urteilskraft naar Blumenbach (KGS11, 145, 211). Maar dan blijft de afwezigheid van een discussie over rassen ${ }^{30}$ en kiemen opmerkelijk aan Kants bespreking van het organisme in dit boek.

Om deze afwezigheid te begrijpen gaan we nogmaals in op Kants vroege teksten. Hij maakt in 1775 veel gebruik van de terminologie van de arts, dichter en natuurwetenschapper Albrecht von Haller (1708-1777), zoals preformatie en kiem. Ook Blumenbach is op dat moment gecharmeerd van Hallers ideeën. ${ }^{31}$ Maar vanaf 1780 wil Blumenbach zich juist meer en meer afzetten van Haller. Hierdoor wijst hij steeds uitdrukkelijker bepaalde begrippen van Haller af, terwijl deze begrippen tot en met 1788 een centrale rol spelen in Kants werk.

In 1788 verwijst Kant in een voetnoot naar Blumenbach: "Deze inzichtelijke man kent ook een vormingsdrang [Bildungstrieb] toe, waardoor hij zoveel duidelijkheid heeft gebracht in de leer van de generaties, niet van anorganische materie, maar slechts van de leden van het georganiseerde wezen." (GTP, 180n) Zoals Bernasconi aanstipt kunnen we hieruit allereerst afleiden dat Kant pas in deze periode (1787-1788) een duidelijke interesse in het werk van Blumenbach heeft ontwikkeld. In dezelfde tekst verwijst hij naar Blumenbachs Handbuch der Naturgeschichte uit 1779. Dit is de eerste uitgave van het boek. Inderdaad bezat Kant een exemplaar. Maar de verwijzing naar deze uitgave is hoogst bevreemdend. 
Het begrip van vormingsdrang heeft Blumenbach in de eerste druk helemaal nog niet gehanteerd. Kant verwijst juist naar dit begrip. Blumenbach is in 1779 nog niet op de vormingsdrang gestuit. Hij schrijft in het vervolg van zijn carrière verschillende versies van het boek. Kant moet dus meer van Blumenbach gelezen hebben. Kants leerling Johann Benjamin Jachmann (17651832) lijkt dit te bevestigen. Hij stuurt op 14 oktober 1790 op verzoek van Blumenbach een boek naar Kant. Het betreft Blumenbachs Beyträge zur Naturgeschichte. Al snel merkt Jachmann in de brief op dat Kant dit boek waarschijnlijk al heeft gelezen (KGS11, 222).

In de eerste versie van zijn Handbuch der Naturgeschichte neemt Blumenbach zonder aarzeling Hallers begrip van kiem over. ${ }^{32}$ Een jaar later maakt Blumenbach een belangrijke wending door. Hij zet zich dan juist af tegen Hallers ideeën over preformatie en kiemen. Vanaf dan verschijnt het begrip van vormingsdrang in zijn werk. Blumenbach komt na een onderzoek naar poliepen op de vormingsdrang. Hij ziet tentakels na enkele dagen weer aangroeien nadat deze geamputeerd zijn hoewel ze dan kleiner zijn dan oorspronkelijk het geval was. Dit kan hij niet verklaren op basis van louter mechanische wetten. Er moet een speciale en ingeboren drang in het organisme zijn die doorheen het leven actief is. Deze drang geeft het georganiseerde leven een vorm, ook als het eenmaal beschadigd is geweest. De ontdekking van de vormingsdrang in 1780 verwerkt Blumenbach al snel in zijn inzichten over de menselijke variaties. Door de ontdekking begint Blumenbach te twijfelen aan Hallers theorie over "voorgevormde kiemen". ${ }^{33}$ Een resolute afwijzing van deze theorie laat niet lang op zich wachten. ${ }^{34}$ Desondanks herkent Kant zijn teleologische principe in Blumenbachs vormingsdrang. Dat Kant in zijn tekst van 1788 verwijst naar de vormingsdrang moet dus wel bevreemdend overkomen bij Blumenbach.

Alsof hij Kant erop wil attenderen dat een begrip als kiem niet in zijn denken past stuurt Blumenbach in 1789 zijn Über den Bildungstrieb op. Enigszins verlaat reageert Kant (5 augustus 1790). Hij bedankt hem voor het toezenden van zijn boek. Tevens uit hij waardering voor Blumenbachs poging om twee principes te verenigen in het begrip van de vormingsdrang. Deze principes zijn namelijk die van "de fysisch-mechanische en de louter teleologische soort van verklaring van de georganiseerde natuur waarvan men vroeger geloofde dat ze onverenigbaar waren" (KGS11, 185). Tevens zendt hij hem een exemplaar van zijn Kritik der Urteilskraft toe. Zoals Kant aangeeft, liggen deze principes dicht bij zijn eigen bevindingen. Hij heeft dus nog net op tijd de impact van Blumenbachs denken kunnen verwerken in zijn Kritik der Urteilskraft. Ter herinnering verwijst Kant in dit boek wederom naar de verdiensten van Blumenbachs begrip van vormingsdrang (KU, §81, 424/326327).

Dit betekent niet dat Blumenbach hier Kant eenzijdig heeft beïnvloed. Kant wil namelijk meer. Blumenbach heeft het begrip van ras nog niet overgenomen. 
Gezien de felle reacties van Herder en Forster begrijpt Kant dat zijn ideeën over rassen voor veel tijdgenoten controversieel zijn. Hij beseft al vroeg dat hijzelf niet in staat is zijn rassentheorie van genoeg feiten te voorzien. Breitkopf vraagt in 1778 na het lezen van 'Von den verschiedenen Racen der Menschen' aan Kant of hij misschien "deze zaak in een meer uitvoerig werk" wil uitwerken (KGS10, 227). Kant antwoordt dat hij in dat geval zijn inzichten moet verbreden. Hij moet dan tevens ingaan op dieren en planten, maar dit ligt "in zekere zin buiten mijn gebied" (KGS10, 230). Blumenbach en Girtanner vullen deze leemte op als zij hun natuurgeschiedenis tevens wijden aan planten en dieren (cf. KGS11, 185).

Kant hoopt echter nog op erkenning voor zijn begrip van ras. ${ }^{35} \mathrm{Hij}$ ziet vooral in de huidskleur van het ras een doelmatigheid van de natuur. Blumenbach richt de aandacht vooral op de schedels en het haar. Zolang Blumenbach net als Forster nog vasthoudt aan het begrip van variëteit in plaats van ras blijft het gevaar aanwezig dat hij niets meer doet dan louter natuurbeschrijving. Dit was waarschijnlijk ook de inzet van Kant als hij in zijn 'Über den Gebrauch teleologischer Principien in der Philosophie' uitgebreid ingaat op het verschil tussen variëteit en ras. Hij wil dat ook Blumenbach dit inziet.

Er verschijnen vele verschillende versies van Blumenbachs Handbuch der Naturgeschichte. Vanaf 1797 verwijst hij naar Kants begrip van ras. ${ }^{36}$ Blumenbach haalt hem regelmatig aan in dit boek. Zodra hij is aangekomen bij de rassenkwestie benadrukt Blumenbach dat Kant het "onderscheid tussen rassen en variëteiten voor het eerst [...] heeft bepaald" ${ }^{37}$ Kant krijgt de erkenning waar hij naar zocht. Blumenbach geeft dan de volgende definitie van het begrip van ras: "Ras betekent in precieze zin een karakter dat door degeneratie ontstaan is, dat door voortplanting onvermijdelijk en noodzakelijk overerft, zoals bijvoorbeeld wanneer blanken met de negers mulatten, of met Amerikaanse indianen mestiezen voortbrengen". ${ }^{38}$ In 1798 maakt hij bij monde van Johann Gottfried Gruber expliciet melding van de invloed van Kant op zijn werk. ${ }^{39}$ Gruber vertaalt Blumenbachs De generis humani varietate nativa en voegt een appendix toe. Nadat hij met Blumenbachs toestemming de invloed van "onze grote Kant" heeft benadrukt schrijft hij: "Overigens weet ik niet waarom de nieuwe schrijvers van de natuurgeschiedenis van de mens zich niet van de door onze grote Kant gestelde bepalingen bedienen. Ik betwijfel of men een preciezere zal vinden."

Zoals Blumenbachs omschrijving van het begrip van ras suggereert, treffen de denkers elkaar in het voorbeeld van de halfbloed. Eén van de centrale thema's die Kant presenteert om zijn theorie over de rassen kracht bij te zetten, is dat van de halfbloed. De aanhangers van polygenese kunnen dit fenomeen niet verklaren. Hoe kunnen we het bestaan van de halfbloed verklaren als de diversiteit van mensen aangeeft dat er een verschil in afkomst is? 
Als Kant de kwestie van de mulat presenteert wil hij een ander begrip van kiem hanteren dan Haller ${ }^{40}$ Kiemen bevinden zich volgens Kant niet alleen aan de zijde van de moeder. Haller en Blumenbach stellen dit dan nog wel. De vader activeert volgens Haller bij de bevruchting de kiem slechts. Maar Kant herkent in de vermenging van de kleur van de verschillende rassen de invloed van beide ouders. Vandaar dat het voorbeeld van de halfbloed van belang is voor Kants vertoog over preformatie en kiemen: de halfbloed vertoont kenmerken van beide ouders die noodzakelijk overgenomen zijn, namelijk de huidskleur.

Vanwege dezelfde reden toont Blumenbach interesse in de mulat. Zodoende concludeert hij later dat Hallers kiemen falen. Vanaf 1780 spreekt Blumenbach steeds vaker over deze kwestie. ${ }^{41}$ In Hallers theorie over preformatie staat het begrip van kiem centraal, zoals Blumenbach dit zelf eerder ook onderschreef. Blumenbach bespreekt de mulat later om ideeën over een 'kiemsysteem' te weerleggen. ${ }^{42}$ Een theorie over preformatie en kiemen verklaart niet hoe mulatten vruchtbaar zijn.

Omdat Blumenbach de preformatie (met de 'voorgevormde kiemen') wil vervangen door de vormingsdrang is het verwonderlijk dat Kant aansluiting bij hem zoekt. Aangezien Blumenbach op dit moment Kants begrip van ras nog niet heeft omarmd, kunnen we Kants koppeling van de rassen en teleologie aan Blumenbachs vormingsdrang in 1788 opvatten als zijn poging om Blumenbach over te halen om de ideeën over rassen serieus te nemen.

In zijn Kritik der Urteilskraft herhaalt Kant dat niets in de voortplanting kan blijven bestaan wat niet doelmatig is. We herkennen de gedachte over de rassen. Tevens schrijft Kant in 1790:

$\mathrm{Nu}$ kan het heel goed zo zijn dat bijvoorbeeld sommige delen in een dierlijk lichaam als groeisels volgens louter mechanische wetten kunnen worden opgevat (bijvoorbeeld huid, botten en haren). In dat geval moet de oorzaak die de geschikte materie daarvoor verschaft en deze materie aldus modificeert, vormt en op de juiste plekken aanbrengt, nog altijd teleologisch worden beoordeeld, en wel zó dat alles in dat lichaam als organisch wordt beschouwd, en dat alles met een bepaalde relatie tot dat lichaam zelf weer orgaan is. $(\mathrm{KU}, \S 66,377 / 276)$

De voorbeelden die Kant aanhaalt herkennen we in het werk van onder anderen Blumenbach. Dit neemt niet weg dat tot dan toe volgens Kant vooral de zwarte huidskleur van de 'neger' het voorbeeld bij uitstek is om een doelmatigheid in de natuur te herkennen. ${ }^{43}$

\section{Kant en Blumenbach in één: Christoph Girtanner (1760-1800)}

Ondanks deze verschillen herkennen anderen de gelijkenissen. We richten ons op Girtanner. Hij studeert van 1780 tot 1782 in Göttingen bij Blumenbach, maar hij herintroduceert ook het begrip van kiem. Ook verdedigt Girtanner het 
systeem van generieke preformatie, en dit beschrijft hij in zijn Über das Kantische Prinzip für die Naturgeschichte: ein Versuch diese Wissenschaft philosophisch zu behandeln in 1796. Het boek is nog wel opgedragen aan Blumenbach. Hoewel Kant het begrip van kiemen uiteindelijk voor een deel lijkt te hebben losgelaten tijdens het schrijven van zijn Kritik der Urteilskraft verschijnt deze in Girtanners boek in samenhang met het begrip van natuurlijke aanleg. ${ }^{44}$ En Girtanner aarzelt niet om deze gedachten te koppelen aan Blumenbachs vormingsdrang.

Wederom speelt Reinhold hier een belangrijke rol: Girtanner zoekt juist zijn hulp als hij meer wil leren over het werk van Kant. Bovendien raakt Girtanner tijdens een verblijf in Edinburgh bevriend met Jachmann die daar colleges over Kants filosofie geeft. Als Jachmann Girtanner in een brief aan Kant uit 1789 introduceert omschrijft hij hem als "een groot kenner en vereerder van uw geschriften". Tevens schrijft Jachmann: "Dr. Girtanner, hoewel u persoonlijk onbekend, in ieder opzicht echter uw kennismaking waard, laat zich meest eerbiedig aan u aanbevelen en verzekert u van zijn grootste hoogachting." (KGS11, 94)

Girtanner zoekt in zijn boek naar een manier de twee denkers te verzoenen. Kant en Blumenbach zien dit maar al te graag gebeuren. Het boek is echter niet met open armen ontvangen. ${ }^{45}$ Hierdoor voelt Girtanner zich gedwongen om zelf anoniem een recensie te schrijven voor het gerenommeerde Göttingische Anzeigen von gelehrten Sachen. ${ }^{46}$ Dit neemt niet weg dat het boek van belang was voor Kant en Blumenbach, twee prominente denkers die hun stempel hebben weten te drukken op de discussies over het rassenonderscheid. ${ }^{47}$ Hoewel Blumenbach zich wilde afzetten van een theorie over preformatie en kiemen wist hij Girtanners werk te waarderen. Niet alleen Kant krijgt dus erkenning van deze wetenschapper uit Göttingen. Vanaf 1797 verwijst Blumenbach in zijn besprekingen van de rassen meermalen naar Girtanner. ${ }^{48}$

Girtanner neemt Kants onderscheid tussen natuurbeschrijving en natuurgeschiedenis over. De invloed van Kant is vooral in het begin van Girtanners boek goed merkbaar. Als hij is aangekomen bij het begrip van kiem bespreekt hij hetzelfde voorbeeld als Kant: de mogelijkheid tot de ontwikkeling van een nieuwe laag veren bij vogels. Hij wijst bovendien op het belang van de drie teksten van de 'grote filosoof te Köningsberg' over de menselijke rassen. Tevens herkent Girtanner het belang van Kants derde kritiek voor het begrip van ras. ${ }^{49} \mathrm{Hij}$ voegt er al snel aan toe dat Kants principe "een algemene wet is welke op de gehele georganiseerde natuur toegepast kan worden" ${ }^{50}$ En zodra Girtanner een definitie moet geven van het begrip van ras citeert hij woordelijk uit Kants 'Bestimmung des Begriffs einer Menschenrace'. Het begrip van ras heeft betekenis voor "het klassenonderscheid van organische lichamen van één en dezelfde stam in zoverre dit onvermijdelijk erfelijk is" (VRM, 100). ${ }^{51}$ 
$\mathrm{Na}$ het verzoek in het voorwoord om erkenning voor zijn poging tot een verzoening moet Girtanner enkele jaren wachten op Kants antwoord. Hij is zeer tevreden met de onderneming zoals hij in zijn Anthropologie in pragmatischer Hinsicht uit 1798 laat blijken. Dan stelt hij dat Girtanners uiteenzetting in overeenstemming is met de (kantiaanse) grondprincipes (APH, 320) ${ }^{52}$ Als Kant naar Girtanner verwijst in het hoofdstuk over het 'karakter van rassen' wil hij hiermee vooral benadrukken hoe vruchtbaar zijn eigen werk is. Kant heeft in de jaren 1790 wetenschappelijke ondersteuning gevonden voor zijn ideeën over het rassenonderscheid.

\section{Tot slot}

Kant heeft volgens zijn tijdgenoten als eerste op een succesvolle manier het rassenonderscheid wetenschappelijk weten te funderen. Keer op keer probeert hij zijn tijdgenoten over te halen zijn begrip van ras serieus te nemen. De wetenschappers moeten inzien dat zijn begrip van ras uitgaat van een principe van doelmatigheid. Het rassenonderscheid is een slimme zet van de natuur. De huidskleur heeft immers een doelmatigheid. Deze is ergens goed voor en in zoverre kent de ontwikkeling van de huidskleur een bijzondere wetmatigheid.

Men heeft vaak gewezen op het belang van Blumenbach voor de ontwikkelingen van het wetenschappelijk onderzoek naar het rassenonderscheid. Vanaf 1786 levert Johann Daniel Metzger (1739-1805) - een collega van Kant uit Köningsberg - meermalen kritiek op Kants natuurgeschiedenis en het begrip van ras. ${ }^{53} \mathrm{Hij}$ wil de invloed van het klimaat nogmaals benadrukken. Hij kon rekenen op sterke kritiek en dit heeft bij hem voor de nodige frustraties gezorgd. In de biografie die hij direct na de dood van Kant in 1804 over hem schrijft, zet Metzger hem weg als iemand die over zaken schrijft waar hij geen verstand van heeft: "Het is duidelijk uit al dat wat sinds Kant betrokken is bij deze materie dat de natuurlijke geschiedenis van de mensheid niet echt het onderwerp was waarin hij voorbestemd was te stralen [...]. Blumenbach, Ludwig en anderen hebben ons beter geleerd. ${ }^{\prime 54}$ Het is opmerkelijk dat Metzger hier de invloed van Kant op het werk van Blumenbach verdraait. Als Metzger wil aanstippen dat we meer van Blumenbach kunnen leren als het gaat om de geschiedenis van de mensheid, dan vergeet hij dat Blumenbach zich heeft bekeerd tot het kantianisme.

In deze discussies staat de kwestie van rassenvermenging en de halfbloed centraal. Aan het begin van de negentiende eeuw is de vraag naar de voor- en nadelen van rassenvermenging nog niet beslist. De eugenetica heeft aan het eind van die eeuw de knoop willen doorhakken: raszuiverheid is verkieslijk. Men verwacht misschien dat de interesse in Kants inzichten gering is na Darwins $O n$ the Origins of Species (1859). Niets is minder waar. De sociaal darwinist Ernst Haeckel (1834-1919) is bekend voor de introductie van Darwin in Duitsland. Hij benadrukt dat Kant één van de meest betekenisvolle voorlopers van Darwin is. ${ }^{55}$ 
Geïnspireerd door Haeckels werk publiceert Fritz Schultze in 1875 het boek Kant und Darwin. Ein Beitrag zur Geschichte der Entwickelungslehre. ${ }^{56}$ In dit boek zijn onder andere Kants teksten over de rassen opnieuw afgedrukt. Mede door deze publicatie ontstaat er aan het eind van de negentiende eeuw een hernieuwde interesse in zijn werk over rassen en biologie. ${ }^{57}$

Hoewel de laatste tien jaar meer literatuur verschijnt over dit thema-mede door het uitstekende werk van Lagier, Zammito, Sloan en Bernasconi - is er tevens een weigering of onwil om onszelf te confronteren met deze geschiedenis. $\mathrm{Al}$ snel wuift men dit probleem weg als een onfilosofisch onderdeel binnen Kants denken, terwijl Kant degene is die het begrip van ras als eerste een serieuze wetenschappelijke betekenis heeft gegeven. Kunnen we ons niet beter richten op bijvoorbeeld Kants ethiek? Deze keuze werpt echter geen licht op de mechanismen van racisme in belangrijke historische teksten. Het laat ons in het duister als het gaat om nieuwe verschijningsvormen van racisme. De keuze om dit thema niet te bespreken, laat de kwestie open hoe we racisme kunnen bekritiseren.

Als we willen voortborduren op de Verlichting dan betekent dit - zoals Bernasconi aanstipt - dat we er niet voor terugdeinzen om alles aan het daglicht brengen. Ook als het gaat om Kants ideeën over rassen. Juist in het geval van Kant. Zoals Bernasconi aangeeft:

Misschien is de enige conclusie die we hieruit kunnen trekken dat we altijd op onze hoede zullen moeten zijn, dat de geschiedenis van het begrip van ras voortdurend zal moeten worden herschreven voor zolang racisme een probleem is, en dat we moeten erkennen dat er een gevaar is in het aannemen van een positie van objectiviteit wanneer we leven in een wereld die voor een groot gedeelte nog steeds gevormd is door een relatief recent en verkeerd begrepen concept van ras. ${ }^{58}$

\section{Noten}

${ }^{1} \mathrm{Ch}$. Girtanner, Über die Kantische Prinzip für die Naturgeschichte. Ein Versuch diese Wissenschaft philosophisch zu behandeln, Göttingen, Vandenhoek en Ruprecht, 1796, pp. 393-394.

${ }^{2}$ Cf. A. de Ulloa, A Voyage to South-America, London, L. Davis en C. Reymers, 1758, band 1, pp. 31-32.

${ }^{3} \mathrm{~W}$. Lawrence, Lectures on physiology, zoology and the natural history of man, Londen, J. Callow, 1819, p. 296.

${ }^{4}$ Alle verwijzingen naar het werk van Kant zijn naar Kants gesammelte Schriften (KGS), herausgegeben von der Deutschen Akademie der Wissenschaften, 29 banden (Berlijn, Walter de Gruyter, 1902-). Verwijzingen naar de Kritik der reinen Vernunft betreffen de standaard A en B paginering van de eerste en tweede uitgaven. Specifieke werken die geciteerd zijn in het corpus van de tekst is op basis van de hieronder vermelde afkortingen. De vertalingen die gebruikt zijn, worden in onderstaande lijst vermeld, en 
afgezien van de Kritik der reinen Vernunft wordt hiernaar verwezen volgend op de verwijzing naar het boek en paginanummer van de Duitse tekst.

APH: Anthropologie in pragmatischer Hinsicht (KGS7).

BBM: Bestimmung des Begriffs einer Menschenracen (KGS8).

GTP: Über den Gebrauch teleologischer Principien in der Philosophie (KGS8).

KRV: Kritik der reinen Vernunft (KGS3 en 4).

Kritik van de zuivere rede, Amsterdam, Boom, 2004.

KU: Kritik der Urteilskraft (KGS5).

Kritiek van het oordeelsvermogen, Amsterdam, Boom, 2009.

MAM: Mutmasslicher Anfang der Menschengeschichte (KGS8).

Vermoedelijk begin van de menselijke geschiedenis, in Kleine werken. Geschriften uit de periode 1784-1795, Kampen en Kapellen, Agora/Pelckmans, 2003, pp. 133-160.

MS: Die Metaphysik der Sitten (KGS6).

PG: Physische Geographie (KGS9).

REC: 'Recensionen von J.G.Herders Ideen zur Philosophie der Geschichte der Menschheit'. Theil 1.2. (KGS8).

RMS: 'Recension von Moscatis Schrift: Von dem körperlichen wesentlichen Unterschiede zwischen der Structur der Thiere und Menschen' (KGS2).

VRM: Von den verschiedenen Racen der Menschen (KGS2).

KGS10: Briefwechsel (1747-1788)

KGS11: Briefwechsel (1789-1794)

KGS15/2: Anthropologie

KGS25: Menschenkunde

${ }^{5}$ R. Bernasconi, 'Kant as an Unfamiliar Source of Racism', in J. K. Ward en T. L. Lott (red.), Philosophers on Race: Critical Essays, Oxford, Blackwell, 2002, p. 159.

${ }_{7}^{6}$ Cf. R. Bernasconi, 'Kant as an Unfamiliar Source of Racism', pp. 159-160.

7 Cf. R. Bernasconi, 'Who Invented the Concept of Race? Kant's Role in the Enlightenment Construction of Race', in R. Bernasconi (red.), Race, Oxford, Blackwell, 2001, p. 9-36.

${ }^{8}$ Cf. R. Lagier, Les races humaines selon Kant, Parijs, PUF, 2004, pp. 180-188.

${ }^{9}$ Cf. R. Bernasconi, 'Kant as an Unfamiliar Source of Racism', pp. 154-159.

${ }^{10}$ Cf. Ch. Girtanner, Über die Kantische Prinzip für die Naturgeschichte. Ein Versuch diese Wissenschaft philosophisch zu behandeln, pp. 39-40.

${ }^{11}$ Zoals Zimmermann in 1778 aangaf, is de invloed van Pallas op deze discussie van cruciaal belang (cf. E.A.W. von Zimmermann, Geographische Geschichte des Menschen und der allgemein verbreiteten vierfüssigen Thiere, Leipzig, Weygandsche Buchhandlung, 1778-1783, band 1, pp. 71-73). Het betreft Peter Simon Pallas' Samlungen historischer Nachrichten über die mongolischen Völkerschaften. Erster Theil (St. Petersburg, Kayserlichen Akademie der Wissenschaften, 1776).

${ }^{12}$ R. Bernasconi, 'Kant as an Unfamiliar Source of Racism', p. 148.

${ }^{13}$ Cf. J.J. Engel (red.), Der Philosoph für die Welt. Zweyter Theil, Leipzig, Dyckische Buchhandlung, 1777, pp. 125-164.

${ }^{14}$ Cf. E.A.W. von Zimmermann, Geographische Geschichte des Menschen und der allgemein verbreiteten vierfüssigen Thiere, band 1, pp. 70-73; p. 102; pp. 109-114; G.S. Klügel, 'Der Philosoph für die Welt. herausgegeben von J.J. Engel. Zweyter Theil. Leipz. 1777. bey Dyck', in Allgemeine Deutsche Bibliothek 35 (1778), p. 334; anoniem, 'Der 
Philosoph für die Welt. herausgegeben von J.J. Engel. 2ter Theil. Leipzig 1777, in der Dyckischen Buchhandlung', in: Der Teutsche Merkur 1 (1778), p. 74.

${ }^{15}$ Cf. P. Moscati, Von dem körperlichen wesentlichen Unterschiede zwischen der Structur der Thiere und der Menschen, Göttingen, Vandenhoeck, 1771.

${ }^{16}$ Cf. J.H. Zammito, The Genesis of Kant's Critique of Judgment, Chicago, The University of Chicago Press, 1992, p. 179.

${ }^{17}$ Bernasconi merkt op: “Als [...] Kant de eerste was om een rigoureus wetenschappelijk begrip van ras voor te stellen, dan was Johann Gottfried von Herder de eerste om dit af te wijzen." (R. Bernasconi, 'Introduction', in R. Bernasconi en T.L. Lott (red.), The Idea of Race, Indianapolis, Hackett Publishing, 2000, p. ix)

${ }^{18}$ J.G. Herder, Ideen zur Philosophie der Geschichte der Menschen, in Werke, München, Carl Hanser Verlag, 2002, Band 3.1, p. 231.

${ }^{19}$ Idem, p. 81.

${ }^{20}$ Idem, p. 159.

${ }^{21}$ Cf. J.H. Zammito, "This inscrutable principle of an original organization": epigenesis and 'looseness of fit' in Kant's philosophy of science', in: Studies in History and Philosophy of Science 34 (2003), pp. 73-109.

${ }^{22}$ K.L. Reinhold, 'Schreiben des Pfarrers zu *** ueber eine Recension von Herders Ideen zur Philosophie der Geschichte der Menschheit', in: Der Teutsche Merkur 1 (1785), pp. 148-174.

${ }^{23}$ G. Forster, 'Noch etwas über die Menschenrassen', p. 68.

${ }^{24}$ Idem, p. 80.

25 Brief van Forster aan Heyne, 20 november 1786, in: Johann Georg Forster's Briefwechsel: nebst einigen Nachrichten von seinem Leben, Leipzig, Brockhaus, 1829, p. 587.

${ }^{26}$ Brief van Forster aan Heyne, 21 januari 1787, in: Johann Georg Forster's Briefwechsel: nebst einigen Nachrichten von seinem Leben, p. 596.

27 Brief van Forster aan Jacobi, 19 november 1788, in: Johann Georg Forster's Briefwechsel: nebst einigen Nachrichten von seinem Leben, p. 710.

28 Brief van Forster aan Heyne, 20 november 1786, in: Johann Georg Forster's Briefwechsel: nebst einigen Nachrichten von seinem Leben, p. 587; brief van Forster aan Jacobi, 19 november 1788, in: Johann Georg Forster's Briefwechsel: nebst einigen Nachrichten von seinem Leben, p. 711.

${ }^{29}$ Brief van Forster aan Camper, 7 mei 1787, in: Johann Georg Forster's Briefwechsel: nebst einigen Nachrichten von seinem Leben, p. 612.

${ }^{30}$ Cf. R. Bernasconi, 'Kant and Blumenbach's Polyps. A neglected Chapter in the History of the Concept of Race', in: S. Eigen en M. Larrimore (red.), The German Invention of Race, p. 80: "Zonder ook maar enige prominente bekeerlingen voor zijn begrip van ras voor zich gewonnen te hebben, zelfs na vijftien jaar van definiëren, en ondanks zijn rigoureuze verdedigingen hiervan tegen de objecties van Herder en Forster, is het weinig verwonderlijk dat Kant geen beroep doet op het ras als bewijs wanneer hij het raamwerk probeert op te stellen waar het begrip van ras uiteindelijk op steunt."

${ }^{31}$ Cf. J.F. Blumenbach, De generis humani varietate nativa, Göttingen, Vandenhoeck, 1776, p. 5.

${ }^{32}$ Cf. J.F. Blumenbach, Handbuch der Naturgeschichte, Göttingen, Johann Christian Dieterisch, 1779, p. 20. 
${ }^{33}$ Cf. J.F. Blumenbach, 'Über den Bildungstrieb (Nisus formativus) und seinen Einfluss auf die Generation und Reproduction', in: Göttingisches Magazin der Wissenschaften und Litteratur 1.5 (1780), p. 256.

${ }^{34}$ Cf. J.F. Blumenbach, 'Über den Bildungstrieb', Göttingen, Johann Christian Dieterich, 1789, p. 24: "Dat geen voorgevormde kiemen pre-existeren [...]".

${ }^{35}$ Cf. R. Bernasconi, 'Kant and Blumenbach's Polyps. A neglected Chapter in the History of the Concept of Race', pp. 82-84.

${ }_{37}^{36}$ Cf. idem, p. 88 n.

${ }^{37}$ J.F. Blumenbach, Handbuch der Naturgeschichte, Göttingen, Dieterich'schen Buchhandlung, 1797, p. 23n.

${ }^{38}$ Idem, p. 23.

${ }^{39}$ J.F. Blumenbach, Über die natürlichen Verschiedenheiten im Menschengeschlechte, Leipzig, Breitkopf en Härtel, 1798, pp. 259-261.

${ }^{40}$ Cf. R. Bernasconi, 'Kant and Blumenbach's Polyps. A neglected Chapter in the History of the Concept of Race', p. 77.

${ }^{41}$ Cf. J.F. Blumenbach, 'Über den Bildungstrieb (Nisus formativus) und seinen Einfluss auf die Generation und Reproduction', pp. 259-260.

${ }_{42}^{42}$ J.F. Blumenbach, Über den Bildungstrieb (1789), p. 68-69.

${ }^{43}$ Cf. R. Bernasconi, 'Kant and Blumenbach's Polyps. A neglected Chapter in the History of the Concept of Race', pp. 83-84.

${ }^{44}$ Ch. Girtanner, Über die Kantische Prinzip für die Naturgeschichte. Ein Versuch diese Wissenschaft philosophisch zu behandeln, p. 11.

${ }^{45}$ Cf. anoniem, 'Ueber das Kantische Prinzip für die Naturgeschichte, von D. Chr. Girtanner', in: Neue allgemeine deutsche Bibliothek 32.2 (1797), pp. 375-379.

${ }^{46}$ De recensie verscheen anoniem in Göttingische Anzeigen von gelehrten Sachen 171 (1796), pp. 1705-1712.

${ }^{47}$ Cf. J.H. Zammito, 'This inscrutable principle of an original organization": epigenesis and 'looseness of fit' in: Kant's philosophy of science', p. 76: "Het is niet gering als zowel Immanuel Kant en Johann Friedrich Blumenbach naar iemands werk verwijzen als de definitieve expositie van een cruciale materie in de levenswetenschap van de achtiende eeuw."

48 J.F. Blumenbach, Handbuch der Naturgeschichte, Göttingen, Johann Christian Dieterich, 1799, p. 24n; J.F. Blumenbach, Über die natürlichen Verschiedenheiten im Menschengeschlechte, p. 261.

${ }^{49} \mathrm{Ch}$. Girtanner, Über die Kantische Prinzip für die Naturgeschichte. Ein Versuch diese Wissenschaft philosophisch zu behandeln, pp. 17-30.

${ }^{50}$ Idem, Vorrede.

${ }_{52}^{51}$ Idem, p. 6.

${ }^{52}$ Cf. R. Bernasconi, 'Kant and Blumenbach's Polyps. A neglected Chapter in the History of the Concept of Race', p. 75.

${ }^{53}$ Cf. J.D. Metzger, 'Über die sogenannten Menschenrassen, wider Herrn Kant', in: Medicinischer Briefwechsel, von einer Gesellschaft Ärzte, Halle, J.J. Gebauer, 1786, band 2; J.D. Metzger, 'Noch ein Wort über die Menschenracen', in: Neues Magazin für Ärzte 10 (1788).

${ }^{54}$ J.D. Metzger, Aeusserungen über Kant, seinen Charakter und seine Meinungen, (geen plaats van publicatie), 1804, pp. 42-43. Het boek werd anoniem gepubliceerd. 
55 Cf. E.H.Ph.A. Haeckel, Natürliche Schöpfungsgeschichte. Gemeinverständliche wissenschaftliche Vorträge über die Entwickelungslehre im allgemeine und diejenige von Darwin, Goethe und Lamarck im besonderen, Berlin, Georg Reimer, 1874, $5^{\mathrm{c}}$ uitgave, pp. 93-94.

${ }^{56}$ F. Schultze, Kant und Darwin. Ein Beitrag zur Geschichte der Entwickelungslehre, Jena, Hermann Dufft, 1875.

${ }^{57} \mathrm{Cf}$. J. Brock, 'Einige ältere Autoren über die Vererbung erworbener Eigenschaften', in Biologisches Centralblatt 8.16 (1888), pp. 491-498.

${ }^{58}$ R. Bernasconi, 'Introduction', in R. Bernasconi (red.), Concepts of Race in the Eighteenth Century, Bristol, Thoemmes Press, 2001, p. xi. 